\title{
Bats in cobwebs of the giant-spider Nephilingis cruentata (Fabricius, 1775) (Araneae: Nephilidae) in Brazil
}

\author{
Fábio André Facco Jacomassa * \\ Marcela Benavides Guzman \\ Matheus Dourado \\ São Paulo State University \\ Avenida 24A, 1515, CEP 13506-900, Rio Claro - SP, Brazil \\ * Corresponding author \\ fabioafj@gmail.com
}

Submetido em 27/03/2015

Aceito para publicação em 01/09/2015

\section{Resumo}

Morcegos em teias da aranha-gigante Nephilingis cruentata (Fabricius, 1775) (Araneae: Nephilidae) no Brasil. Em todo o mundo morcegos são vítimas principalmente de vertebrados, mas também são atacados por invertebrados. Relatamos aqui dois casos de morcegos enredados em teias da aranha-gigante Nephilingis cruentata, no sudeste do Brasil. No primeiro, ocorrido em dezembro de 2012, uma fêmea de Eptesicus diminutus foi encontrada morta, e no segundo, ocorrido em março de 2013, um macho de Tadarida brasiliensis foi retirado vivo da teia e liberado. Os animais não apresentavam marcas de predação e ambos os eventos foram registrados após fortes chuvas. Suspeita-se que os morcegos podem ter se emaranharado nas teias quando buscavam abrigo da chuva ou caçavam insetos. Mesmo que esses morcegos não tenham sido predados, esta espécie de aranha não deve ser descartada como um predador oportunista de pequenos morcegos, como observado em outras regiões fora do Brasil.

Palavras-chave: Armadilha natural; Molossidae; Predação; Vespertilionidae

\section{Abstract}

Bats throughout the world are preyed upon primarily by vertebrates, but some are also attacked by invertebrates. We report two cases of bats entangled in webs of the giant-spider Nephilingis cruentata in southeastern Brazil. The first incidence occurred in December 2012, on which a female Eptesicus diminutus was found dead. The second occurred in March 2013, in which a male Tadarida brasiliensis was removed from the web alive, and later released. The animals showed no predation marks on the body, and both events were recorded after heavy rains. We suspect that the bats may have become entangled in the webs while seeking shelter from rain, or while foraging for insects. Even though the bats were not preyed upon, this spider cannot be ruled out as an opportunistic predator of small bats, as has been observed outside of Brazil.

Key words: Molossidae; Natural trap; Predation; Vespertilionidae 
Small bats throughout the world fall prey mainly to vertebrates, such as mammals, birds, snakes, amphibians, and pet animals (BORDIGNON, 2005; KAŇUCH; BALÁŽ, 2005; LEFEVRE, 2005; ESBERARD et al., 2006; ESBERARD; VRCIBRADIC, 2007; CASTRO et al., 2011; KHLAFALLA; IUDICA, 2012; ANCILLOTTO et al., 2013; GARRIDOGARCÍA et al., 2013), however they are also attacked by invertebrates such as large arthropods (MOLINARI et al., 2005; NYFFELER; KNÖRNSCHILD, 2013).

Although the number of reports has grown in the last decade, knowledge of invertebrate bat predators is poor (NYFFELER; KNÖRNSCHILD, 2013), which limits our understanding of the impact of predation events on bat populations. In a recent review, 52 cases were reported globally of bats being captured by spiders (NYFFELER; KNÖRNSCHILD, 2013), $88 \%$ of which were ascribed to web-building spiders, and the rest $(12 \%)$ to hunting spiders. These cases include approximately 24 bat species belonging to five families (Vespertilionidae (64\%), Emballonuridae (22\%), Hipposideridae (8\%), Phyllostomidae (3\%), and Rhinolophidae (3\%), with weight between 2-15 $\mathrm{g}$ ), and 17 spider species belonging to five families (Theraphosidae, Sparassidae, Pisauridae, Nephilidae and Araneidae). Seventy-three percent of the known cases of bat captures were by orb-weaving spiders, and the dominant group of bat-catching spiders is giant orb-weavers in family Nephilidae (46\%). Seventy nine percent of the bats captured by Nephilidae died from exhaustion, starvation, dehydration or hyperthermia, or were killed by the spider, while $41 \%$ were either killed and eaten or bitten by the spider. Only a few escaped or were released by researchers. There is one record of a bat found in a web of the giant-spider Nephilingis cruentata (Fabricius, 1775) in Swaziland, Africa, in which case the captured bat (unidentified) escaped before being bitten (NYFFELER; KNÖRNSCHILD, 2013).

The two cases reported herein are the first in Brazil. The authors identified bat species using Miranda et al. (2011), and spiders were identified by a specialist (José P.L. Guadanucci).

The first case occurred on December 9, 2012 at $15 \mathrm{~h} 30 \mathrm{~min}$, on building wall at approximately $8 \mathrm{~m}$ above the ground at the São Paulo State University at Rio Claro campus, São Paulo state, southeastern Brazil (4732'40'W, 22 23'47'S). The bat was an adult female diminutive serotine bat (Eptesicus diminutus Osgood, 1915) (Vespertilionidae) (Figure 1). The specimen was found dead without holes, missing body parts, or other evidence of predation, as well as without rigor mortis and with elasticity in patagium, indicating recent death. It likely died from exhaustion, starvation, dehydration, or hyperthermia. The specimen was deposited in the Zoology Museum of the State University of Campinas, Brazil - ZUEC-MAM 2709. The second case was an adult male Brazilian free-tailed bat (Tadarida brasiliensis (I. Geoffroy, 1824), belonging to family Molossidae. The bat was found on March 23, 2013 at $14 \mathrm{~h} 00 \mathrm{~min}$ in the same location. The bat was alive with no signs of predation, and was freed by researchers. Both incidents took place after heavy rains.

Nephilingis cruentata is an arboreal spider that naturally occurs in tropical and subtropical Africa. In southeastern Brazil this giant-spider is an exotic species, commonly found on buildings in São Paulo (SCHUCK-PAIM; ALONSO, 2001; NĂPĂRUS; KUNTNER, 2012). This spider weaves orb-webs up to $1 \mathrm{~m}$ in diameter and at a height of 1 to $6 \mathrm{~m}$ above the ground, typically on the corners of walls and ceilings (SCHUCK-PAIM, 2000; DINIZ, 2011). They also spin webs strong enough to withstand the kinetic energy of the struggling bats without breaking (NYFFELER; KNÖRNSCHILD, 2013).

These bats probably entangled in the spider webs while taking shelter from heavy rain. Both bats species are open space and forest edge aerial insectivores (DENZINGER; SCHNITZLER, 2013), and were probably seeking refuge. These incidents occurred perhaps because the bats miscalculated how close they were to the web while in flight foraging for insects (NORQUAY et al., 2010; PIGAGE et al., 2011), since bats are likely capable of detecting spider webs by means of echolocation (NYFFELER; KNÖRNSCHILD, 2013). According Nyffeler and Knörnschild (2013) not only the webs, but also the spiders (in particular the huge, adult female Nephila spp.) presumably generate strong echoes that the echolocating bats should be able 
to detect, advertising the presence of obstacles that should be avoided.

FIGURE 1: Adult female diminutive serotine bat entangled in a web of the giant-spider Nephilingis cruentata.

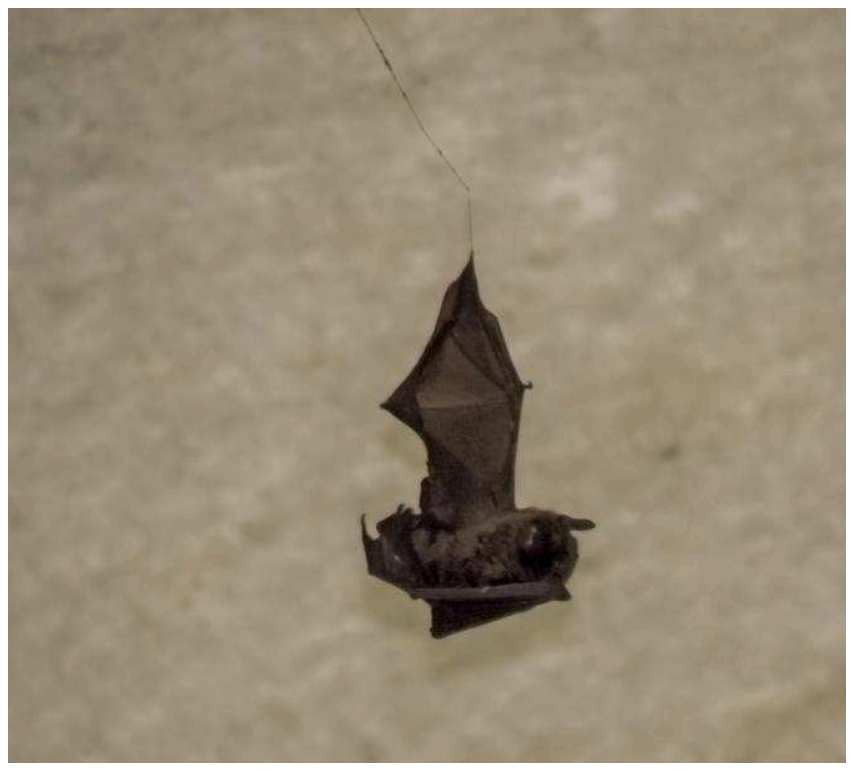

Even though these bats did not fall prey to the spider, there are records of small bats (4-8 g) killed by Nephilids (NYFFELER; KNÖRNSCHILD, 2013). The diminutive serotine bat in this study weighed $4 \mathrm{~g}$, and the brazilian free-tailed bat weighed $11 \mathrm{~g}$; their weights are within the range of bat species found in spider webs (2-15 g, see NYFFELER; KNÖRNSCHILD, 2013). Therefore, they may be considered potential prey, as giant-spiders demonstrate a certain selectivity and opportunism in their choice of prey (JAPYASSÚ; VIERA, 2002). This spider species should not be ruled out as a predator of small bats because it is known to capture and eat several types of vertebrates, including small lizards and birds (DUCA; MODESTO, 2007; PELOSO; SOUSA, 2007; DINIZ, 2011).

These spider webs can be considered an occasional natural trap for small bats, which results in the death of some individuals. Our reports adds two species (and one family) of bats to the list of those likely to be vulnerable to predation by spiders, thus contributing to the general knowledge of predator-prey relationships between spiders and bats.

\section{Acknowledgements}

We thank Susi M. Pacheco, Adolfo S. Melo and anonymous reviewers for invaluable contributions to the manuscript. We thank José P. L. Guadanucci for spider identification and Carmen Viera for help with the bibliography. FAFJ was granted a scholarship by Capes, and $\mathrm{MBG}$ and $\mathrm{MD}$ were granted scholarships by CNPq.

\section{References}

ANCILlOTTO, L.; SERANGELI, M. T.; RUSSO, D. Curiosity killed the bat: domestic cats as bat predators. Mammalian Biology, Jena, v. 78, n. 5, p. 369-373, 2013

BORDIGNON, M. O. Predação de morcegos por Chrotopterus auritus (Peters) (Mammalia, Chiroptera) no pantanal de Mato Grosso do Sul, Brasil. Revista Brasileira de Zoologia, Curitiba, v. 22, n. 4, p. 1207-1208, 2005.

CASTRO, I. J.; SILVA, C. R.; DA COSTA, A. J. S.; MARTINS, A. C. M. Predação oportunista de Artibeus planirostris (Spix, 1823) e Carollia perspicillata (Linnaeus, 1758) (Chiroptera, Phyllostomidae) por marsupiais e anuro no APA do Rio Curiaú, Amapá, Brasil. Acta Amazonica, Manaus, v. 41, n. 1, p. 171-174, 2011.

DENZINGER A.; SCHNITZLER H. U. Bat guilds, a concept to classify the highly diverse foraging and echolocation behaviors of microchiropteran bats. Frontiers in Physiology, New York, v. 4, p. 164-172, 2013.

DINIZ, S. Predation and feeding on the tropical house gecko Hemidastylus mabouia (Squamata: Gekkonidae) by the giant orb-weaver spider Nephilengys cruentata (Araneae: Nephilidae). Herpetology Notes, Pisa, v. 4, p. 357-358, 2011.

DUCA, C.; MODESTO, W. Spider web as a natural trap for small birds. Revista Brasileira de Ornitologia, São Leopoldo, v. 15, n. 4, p. 615-616, 2007.

ESBERARD, C. E. L.; JORDÃO, T.; COSTA, L. M.; BERGALLO, H. G. Leptodactylus labyrinthicus (Labyrinthicus frog). Prey. Herpetological Review, St. Louis, v. 37, p. 204, 2006.

ESBERARD, C. E. L.; VRCIBRADIC, D. Snakes preying on bats: new records from Brazil and a review of recorded cases in the Neotropical Region. Revista Brasileira de Zoologia, Curitiba, v. 24, n. 3, p. 848-853, 2007.

GARRIDO-GARCÍA, J.A.; SCHREUR, G.; PLEGUEZUELOS, J. M. Ocasional bat predation by the horseshoe whip snake (Reptilia, Colubridae). Galemys, Malaga, v. 25, p. 59-61, 2013.

JAPYASSÚ, H.F.; VIERA, C. Predatory plasticity in Nephilengys cruentata (Araneae: Tetragnathidae): relevance for phylogeny reconstruction. Behaviour, Leiden, v. 139, n. 4, p. 529-544, 2002.

KAŇUCH, P.; BALÁŽ, P. Bat as a prey of Elaphe longissima (Laurenti, 1768). Herpetozoa, Berlin, v. 18, n. 1/2, p. 92-93, 2005.

KHALAFALlA S. M.; IUDICA, C. A. Barn Owl (Tyto alba) predation on Big Brown Bats (Eptesicus fuscus) in Pennsylvania. Canadian Field-Naturalist, Ontario, v. 126, p. 38-40, 2012. 
LEFEVRE, K. L. Predation of a bat by American crows, Corvus brachyrhynchos. Canadian Field-Naturalist, Ontario, v. 119, p. 443-444, 2005.

MIRANDA, J. M. D.; BERNARDI, I. P.; PASSOS, F. C. Chave ilustrada para determinação dos morcegos da Região Sul do Brasil. Curitiba: J.M.D. Miranda, 2011. 51 p.

MOLINARI, J.; GUTIÉRREZ, E. E.; ASCENÇÃO, A. A.; NASSAR, J. M.; AREND, A. A.; MÁRQUEZ, R. J. Predation by giant centipedes, Scolopendra gigantea, on three species of bats in a Venezuelan cave. Caribbean Journal of Science, Mayaguëz, v. 41, n. 2, p. 340-346, 2005.

NĂPĂRUS, M.; KUNTNER, M. A GIS model predicting potential distributions of a lineage: a test case on hermit spiders (Nephilidae: Nephilengys). PLOS ONE, Cambridge, v. 7, n. 1, e30047, 2012.

NORQUAY, K. J. O.; MENZIES, A. K.; MCKIBBIN, C. S.; TIMONIN, M. E.; BALOUN, D. E.; WILLIS C. K. R. Silverhaired bats (Lasionycteris noctivagans) found ensnared on burdock (Arctium minus). Northwestern Naturalist, Olympia, v. 91, n. 3, p. $339-342,2010$.
NYFFELER, M.; KNÖRNSCHILD, M. Bat predation by spiders. PLOS ONE, Cambridge, v. 8, n. 3, e58120, 2013.

PELOSO, P. L.; SOUSA, V. P. Predation on Todirostrum cinereum (Tyrannidae) by the orb-web spider Nephilengys cruentata (Araneae, Nephilidae). Revista Brasileira de Ornitologia, São Leopoldo, v. 15, n. 3, p. 461-463. 2007.

PIGAGE, J. C.; BUNN, R. L.; PEYTON, R. D. Multiple bats entangled on cactos. The Prairie Naturalist, Brookings, v. 43, n. 1/2, p. 64-65, 2011.

SCHUCK-PAIM, C. Orb-webs as extended-phenotypes: web design and size assessment in contests between Nephilengys cruentata females (Araneae, Tetragnathidae). Behaviour, Groningen, v. 137, n. 10, p. 1331-1347, 2000.

SCHUCK-PAIM, C.; ALONSO, W. J. Deciding where to settle: conspecific attraction and web site selection in the orb-web spider Nephilengys cruentata. Animal Behaviour, St Andrews, v. 62, n. 5, p. 1007-1012, 2001 